\title{
Self healing in polymers and polymer composites. Concepts, realization and outlook: A review
}

\author{
Y. C. Yuan 1 , T. Yin 1, M. Z. Rong 2 , M. Q. Zhang2* \\ ${ }^{1}$ Key Laboratory for Polymeric Composite and Functional Materials of Ministry of Education, OFCM Institute, \\ School of Chemistry and Chemical Engineering, Zhongshan University, Guangzhou 510275, P. R. China \\ ${ }^{2}$ Materials Science Institute, Zhongshan University, Guangzhou 510275, P. R. China
}

Received 10 February 2008; accepted in revised form 21 February 2008

\begin{abstract}
Formation of microcracks is a critical problem in polymers and polymer composites during their service in structural applications. Development and coalescence of microcracks would bring about catastrophic failure of the materials and then reduce their lifetimes. Therefore, early sensing, diagnosis and repair of microcracks become necessary for removing the latent perils. In this context, the materials possessing self-healing function are ideal for long-term operation. Self-repairing polymers and polymer composites have attracted increasing research interests. Attempts have been made to develop solutions in this field. The present article reviews state-of-art of the achievements on the topic. According to the ways of healing, the smart materials are classified into two categories: (i) intrinsic self-healing ones that are able to heal cracks by the polymers themselves, and (ii) extrinsic in which healing agent has to be pre-embedded. The advances in this field show that selection and optimization of proper repair mechanisms are prerequisites for high healing efficiency. It is a challenging job to either invent new polymers with inherent crack repair capability or integrate existing materials with novel healing system.
\end{abstract}

Keywords: smart polymers, polymer composites, self-healing, cracks

\section{Introduction}

Polymers and polymer composites have been widely used in tremendous engineering fields because of their advantages including light weight, good processibility, chemical stability in any atmospheric conditions, etc. However, long-term durability and reliability of polymeric materials are still problematic when they serve for structural application [1]. Exposure to harsh environment would easily lead to degradations of polymeric components. Comparatively, microcracking is one of the fatal deteriorations generated in service, which would bring about catastrophic failure of the materials and hence significantly shorten lifetimes of the structures.

*Corresponding author, e-mail: ceszmq@mail.sysu.edu.cn

(C) BME-PT and GTE
Since the damages deep inside materials are difficult to be perceived and to repair in particular, the materials had better to have the ability of self-healing. In fact, many naturally occurring portions in animals and plants are provided with such function [2-6]. In the case of healing of a skin wound, for example, the defect is temporarily plugged with a fibrin clot, which is infiltrated by inflammatory cells, fibroblasts, and a dense capillary plexus of new granulation tissue. Subsequently, proliferation of fibroblasts with new collagen synthesis and tissue remodeling of the scar become the key steps. For healing of a broken bone, similar processes are conducted, including internal bleeding forming a fibrin clot, development of unorganized fiber mesh, calcification of fibrous cartilage, conversion of cal- 
cification into fibrous bone and lamellar bone. Clearly, the natural healing in living bodies depends on rapid transportation of repair substance to the injured part and reconstruction of the tissues. Having been inspired by these findings, continuous efforts are now being made to mimic natural materials and to integrate self-healing capability into polymers and polymer composites. The progress has opened an era of new intelligent materials.

On the whole, researches in this field are still in the infancy. More and more scientists and companies are interested in different aspects of the topic. Innovative measures and new knowledge of the related mechanisms are constantly emerging. Therefore, it might be the right time to review the attempts carried out so far in different laboratories in the world. According to the ways of healing, self-healing polymers and polymer composites can be classified into two categories: (i) intrinsic ones that are able to heal cracks by the polymers themselves, and (ii) extrinsic in which healing agent has to be preembedded.

\section{Intrinsic self-healing}

The so-called intrinsic self-healing polymers and polymer composites are based on specific performance of the polymers and polymeric matrices that enables crack healing under certain stimulation (mostly heating). Autonomic healing without external intervention is not available in these materials for the time being. As viewed from the predominant molecular mechanisms involved in the healing processes, the reported achievements consist of two modes: (i) physical interactions, and (ii) chemical interactions.

\subsection{Self-healing based on physical interactions}

Compared to the case of thermosetting polymers, crack healing in thermoplastic polymers received more attention at an earlier time. Wool and coworkers systematically studied the theory involved $[7,8]$. They pointed out that the healing process goes through five phases: (i) surface rearrangement, which affects initial diffusion function and topological feature; (ii) surface approach, related to healing patterns; (iii) wetting, (iv) diffusion, the main factor that controls recovery of mechanical properties, and (v) randomization, ensuring disappearance of cracking interface. In addition, Kim and Wool [9] proposed a microscopic model for the last two phases on basis of reptation model that describes longitudinal chain diffusion responsible for crack healing.

Accordingly, Jud and Kaush [10] tested crack-healing behavior in a series of poly(methyl methacrylate) (PMMA) and poly(methyl methacrylate-comethyl ethylacrylate) (MMA-MEA copolymer) samples of different molecular weights and degrees of copolymerization. They induced crack healing by heating samples above the glass transition temperature under slight pressure. It was found that full resistance was regained during short term loading experiments. The establishment of mechanical strength should result from interdiffusion of chains and formation of entanglements for the glassy polymer [11]. Wool [12] further suggested that the recovery of fracture stress is proportional to $t^{1 / 4}$ (where $t$ is the period of heating treatment). Jud et al. [13] also performed re-healing and welding of glassy polymers (PMMA and styrene-acrylonitrile copolymer (SAN)) at temperatures above the glass transition temperatures, and found that the fracture toughness, $K_{l i}$, in the interface increased with contact time, $t$, as $K_{l i} \propto t^{1 / 4}$ as predicted by the diffusion model.

It is worth noting that whereas craze healing occurs at temperature above and below the glass transition temperature [14], crack healing happens only at or above the glass transition temperature [15]. In order to reduce the effective glass transition temperature of PMMA, Lin et al. [16] and Wang et al. [17] treated PMMA with methanol and ethanol, respectively. They reduced the glass transition temperature to a range of $40 \sim 60^{\circ} \mathrm{C}$, and found that there were two distinctive stages for crack healing: the first one corresponding to the progressive healing due to wetting, while the second related to diffusion enhancement of the quality of healing behavior.

Besides simple heating induced healing, thermomechanical healing is valid for some specific polymers, like poly(ethylene-co-methacrylic acid) (EMAA) copolymers [18]. EMAA films prove to be able to heal upon ballistic puncture and sawing damages. This occurs through a heat generating frictional process, which heats the polymer to the viscoelastic melt state and provides the ability to rebond and repair damage. In contrast, low speed 
friction event fails to produce sufficient thermal energy favorable to healing. As a result, thermomechanical healing is not active in the material.

Unlike thermoplastics, heating induced healing of thermosetting polymers depends on crosslinking of unreacted groups. Healing of epoxy, for instance, has to proceed above the glass transition temperature [19]. Then, the molecules at the cracking surfaces would interdiffuse and the residual functional groups react with each other. A 50\% recovery of impact strength can thus be obtained [20]. During the repair study of vinyl ester resin, Raghavan and Wool reported critical strain energy release rate, $G_{I C}$, for the interfaces after crack healing (i.e. annealing above the glass transition temperature) is $1.7 \%$ of the virgin value. Lower crosslink density favors the repair effect [21].

Thermoplastic/thermosetting semi-interpenetrating network is factually a material associated with repeatable self-healing ability. The group of Jones introduced a soluble linear polymer to a thermosetting epoxy resin [22-24]. The selected thermoplastic is poly(bisphenol-A-co-epichlorohydrin), which is highly compatible with the matrix diglycidyl ether of bisphenol-A based resin. Upon heating a fractured resin system, the thermoplastic material would mobilize and diffuse through the thermosetting matrix, with some chains bridging closed cracks and thereby facilitating healing. When this healable resin was compounded with crossply glass fiber, effective healing of composites transverse cracks and delamination has been demonstrated. The requirements for such thermal diffusion of a healing agent were summarized as follows [23]. (i) The healing agent should be reversibly bonded (e.g. through hydrogen bonding) to the crosslinked network of the cured resin below the minimum healing temperature to limit its effect on thermomechanical properties. (ii) The healing agent should become mobile above this minimum healing temperature so that it can diffuse across a hairline crack, such as a transverse crack, to provide a recovery in strength. (iii) The addition of the linear chain molecule should not significantly reduce the thermomechanical properties of the resin matrix.

\subsection{Self-healing based on chemical interactions}

In fact, cracks and strength decay might be caused by structural changes of atoms or molecules, like chain scission. Therefore, inverse reaction, i.e. recombination of the broken molecules, should be one of the repairing strategies. Such method does not focus on cracks healing but on 'nanoscopic' deterioration. One example is polycarbonate (PC) synthesized by ester exchange method. The PCs were treated in a steam pressure cabin at $120^{\circ} \mathrm{C}$ prior to the repair [25]. As a result, molecular weight of the PCs dropped by about 88 to $90 \%$. After drying them in a vacuum cabin, the repairing treatment was done in an oven at $130^{\circ} \mathrm{C}$ with $\mathrm{N}_{2}$ atmosphere under reduced pressure. The reduced tensile strength due to the deterioration treatment can thus be gradually recovered. The repairing mechanism was considered as the following procedures. Firstly the carbonate bond was cut by hydrolysis, and then the concentration of the phenoxy end increased after deterioration. The $(-\mathrm{OH})$ end-group on the chain was substituted by sodium ion. The $(-\mathrm{ONa})$ end might attack a carbonate bond at the end of one of the other chains, leading to recombination of these two chains with the elimination of the phenol from PC (Figure 1). The repairing reaction was accelerated by weak alkaline, such as sodium carbonate. It suggested that two conditions are required for the PC to re-combine the polymer chains. One is the chemical structure of the chain end and the other is the catalyst $\left(\mathrm{Na}_{2} \mathrm{CO}_{3}\right)$ for acceleration of the reaction.

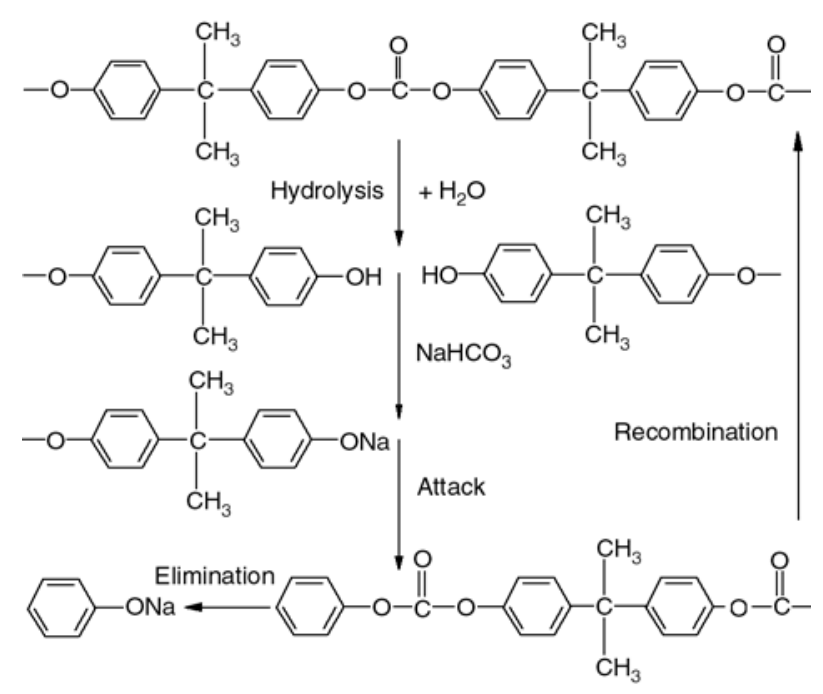

Figure 1. Hydrolysis and recombination reaction of PCs with the catalyst of $\mathrm{NaCO}_{3}$ 
Another example is poly(phenylene ether) (PPE) in which the repairing agent was regenerated by oxygen [26]. The polymer chain of the PPE was cut by a deterioration factor (such as heat, light, and external mechanical force) to produce a radical on the end of the scission chain. Subsequently, a hydrogen donor stabilized the radical. The catalyst existing in the system, $\mathrm{Cu}$ (II), would react with each end of the scission chains to form a complex. Then, the chains combined by eliminating two protons from the ends, and the copper changed from $\mathrm{Cu}$ (II) to $\mathrm{Cu}(\mathrm{I})$. Afterward, two $\mathrm{Cu}(\mathrm{I})$ reacted with an oxygen molecule to be oxidized to $\mathrm{Cu}$ (II), and an oxygen ion reacted with two protons to form a water molecule that evaporated from the specimen.

The above examples show that PC or PPE might be probably designed as a self-repairing material by means of the reversible reaction. The deterioration is expected to be minimized if the recovery rate is the same as the deterioration rate. However, the systems in these studies are not sufficient for construction of real self-repairing composites because the recovery of the broken molecules needs higher temperature and other rigorous conditions. A much more effective catalyst should be found, which is able to active the recombination of degraded oligomers at room temperature.

Thermally reversible crosslinking behavior has been known for quite a while. Wudl et al. combined this with the concept of 'self-healing' in making healable polymers [27, 28]. They synthesized highly cross-linked polymeric materials with multifuran and multi-maleimide via Diels-Alder (DA) reaction. At temperatures above $120^{\circ} \mathrm{C}$, the 'intermonomer' linkages disconnect (corresponding to retro-DA reaction) but then reconnect upon cooling (i.e. DA reaction). This process is fully reversible and can be used to restore fractured parts of the polymers. The polymers are transparent and possess mechanical properties comparable to commercial epoxy and unsaturated polyester. In principle, an infinite number of crack healing is available without the aid of additional catalysts, monomers and special surface treatment.

In a latter work by Liu and Hsieh [29], Wudl's approach was modified. The multifunctional furan and maleimide compounds were prepared in simple routes, using epoxy compounds as precursors. The furan and maleimide monomers could be therefore considered as epoxy-based compounds, so as to incorporate the advantage characteristics of epoxy resins, including solvent and chemical resistance, thermal and electrical characters, and good adherence, to their corresponding cured polymers. Besides, Liu and Chen prepared polyamides possessing furan pendent groups (PA-F) from reacting furfuryl amine with maleimide containing polyamides (PA-MI) via a Michael addition reaction [30]. Thermally reversible cross-linked polyamides were obtained from PA-MI and PA-F polyamides by means of DA and retro-DA reactions. The thermally reversible cross-linked polyamides also exhibited a self-repairing property as well as the ability of mechanical property recovery. To quantify the degree of structural restoration after damages have been repaired, characterization of healing efficiency is necessary but no specific testing standard is available now. Different testing procedures sometimes give different results [23]. When Wudl's group measured healing efficiency of their thermally reversible crosslinked polymers, fracture toughness from compact tension (CT) tests was used [27]. Values for the original and healed fracture toughness were determined by the propagation of the starter crack along the middle plane of the specimen at the critical load. In consideration of the difficulties in (i) precise registration of the fracture surface and (ii) protection of pre-notching, Plaisted and Nemat-Nasser [31] applied double cleavage drilled compression (DCDC) to evaluate mending efficiency of the reversibly cross-linked polymer based on Diels-Alder cycloaddition. The testing geometry allowed for controlled incremental crack growth so that the cracked sample remained in one piece after the test, improving ability to realign the fracture surfaces prior to healing.

\section{Extrinsic self-healing}

In the case of extrinsic self-healing, the matrix resin itself is not a healable one. Healing agent has to be encapsulated and embedded into the materials in advance. As soon as the cracks destroy the fragile capsules, the healing agent would be released into the crack planes due to capillary effect and heals the cracks. In accordance with types of the containers, there are two modes of the repair activity: (i) self-healing in terms of healant loaded pipelines, and (ii) self-healing in terms of healant loaded microcapsules. Taking the advantages of crack trig- 
gered delivery of healing agent, manual intervention (e.g. heating that used to be applied for intrinsic self-healing) might be no longer necessary.

\subsection{Self-healing in terms of healant loaded pipelines}

\subsubsection{Hollow glass tubes and glass fibers}

The core issue of this technique lies in filling the brittle-walled vessels with polymerizable medium, which should be fluid at least at the healing temperature. Subsequent polymerization of the chemicals flowing to the damage area plays the role of crack elimination. Dry first identified the potential applicability of hollow glass tubes [32-35]. Similar approach was adopted by Motuku et al. [36] and Zhao et al. [37]. Because the hollow glass capillaries have diameters (on millimeter scale) much larger than those of the reinforcing fibers in composites, they have to act as initiation for composites failure [38]. Instead, Bleay et al. employed hollow glass fiber (with an external diameter of $15 \mu \mathrm{m}$ and an internal diameter of $5 \mu \mathrm{m}$ ) to minimize the detrimental effect associated with large diameter fibers [38]. Complete filling of healing agent into the tiny tubes was achieved by vacuum assisted capillary action filling technique.

Accordingly, three types of healing system were developed (Figure 2) [32-48]. (i) Single-part adhe-
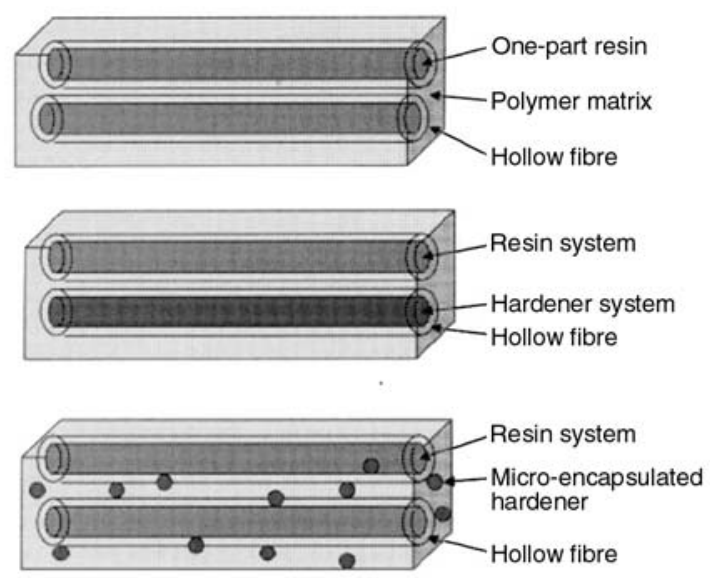

Figure 2. Schematic diagram of repair concept for polymer matrix composites using pre-embedded hollow tubes [38] (Reprinted from Composites Part A: Applied Science and Manufacturing, Vol 32, Bleay S. M., Loader C. B., Hawyes V. J., Humberstone L., Curtis P. T.: A smart repair system for polymer matrix composites, 1767-1776, Copyright (2001), with permission from Elsevier) sive. All hollow pipettes contained only one kind of resin like epoxy particles (that can be flowable upon heating and then cured by the residual hardener) or cyanoacrylate (that can be consolidated under the induction of air). (ii) Two-part adhesive. In general, epoxy and its curing agent were used in this case. They were filled into neighboring hollow tubes, respectively. (iii) Two-part adhesive. One component was incorporated into hollow tubes and the other in microcapsules.

With the aid of the pre-embedded healing system in hollow pipettes, Motuku and co-workers studied the healing ability of glass fiber/unsaturated polyester composites subjected to low velocity impact $[36,43]$. The species of healing agent, characteristic parameters of the hollow pipes (amount, type of tubing materials and spatial distribution), composites panel thickness, and impact energy level were found to be critical to the healing efficiency. Meanwhile, Bleay et al. proved that the epoxy based composites reinforced by hollow glass fibers containing solvent diluted two-part epoxy became repairable as assessed by compression after impact test [38].

Recently, Trask et al. [47] considered the placement of self-healing hollow glass fibers layers within both glass fibre/epoxy and carbon fibre/ epoxy composite laminates to mitigate damage and restore mechanical strength. The hollow fibers were bespoken with diameters between 30 and $100 \mu \mathrm{m}$ and a hollowness of approximately $50 \%$. The study revealed that after the laminates were subjected to quasi-static impact damage, a significant fraction of flexural strength can be restored by the self repairing effect of a healing resin stored within hollow fibers. More details of such healing system can be found in ref. [44-46, 48]. For example, Pang et al. added UV fluorescent dye to the healing resin within the hollow fibers so that bleeding of the repair substance in the composites can be visualized [44].

On the other hand, step type multi-mode quartz optical fiber consisting of hollow fiber, cladding and coating have been successfully applied in smart structures. When the materials were damaged, the pre-embedded optical fibers had to be ruptured leading significant reduction in the output light intensity. This helped to locate the cracked portions. In case the hollow optical fibers were infused with uncured resin and embedded within polymer 
composites, real-time monitor, diagnosis and repair of damages would be simultaneously completed. Guided by this idea, Yang and co-workers manufactured glass fiber laminates with self-diagnosis and self-healing functionality, in which ethyl cyanoacrylate served as the healant. Recoveries of initial tensile strength of about $1 / 3$ and initial compressive strength of about $2 / 3$ proved the feasibility of this approach [49-51].

Property matching is important for hollow glass fibers/matrix polymer pairs, which decides breakage of the hollow fibers and release of healing agent. Zhao et al. showed that for the epoxy/polyamide compounds with healing agent loaded hollow plastic fiber, the plastic tubes did not fracture even when the matrix was completely broken [37]. No healing effect could be observed as a result. One of the possible solutions of this problem lies in covering the hollow repair fiber with a thin polymeric layer [39, 52]. By tuning species and thickness of the polymer coating, one might be able to control fracture mode and time of the containers, giving out healant at the right moment.

Flowability of the released healing agent inside materials to be healed is another problem that might be encountered in practice. Besides diffusivity of the healing agent itself, internal pressure within the repair tubes should also be considered. Having carefully studied dependences of the spillage of healing fluid and the repair area, Zhao and co-workers indicated that $95 \%$ of the crack planes can be healed when the internal pressure reached 0.2 MPa [37].

\subsubsection{Three-dimensional microvascular networks}

In conventional extrinsic self-healing composites it is hard to perform repeated healing, because rupture of the embedded healant-loaded containers would lead to depletion of the healing agent after the first damage. To overcome this difficulty, Toohey et al. proposed a self-healing system consisting of a three-dimensional microvascular network capable of autonomously repairing repeated damage events [53]. Their work mimicked architecture of human skin. When a cut in the skin triggers blood flow from the capillary network in the dermal layer to the wound site, a clot would rapidly form, which serves as a matrix through which cells and growth factors migrate as healing ensues. Owing to the vascular nature of this supply system, minor damage to the same area can be healed repeatedly. The 3D microvascular networks were fabricated by deposition of fugitive ink (a mixture of Vaseline/microcrystalline wax (60/40 by weight)) in terms of direct-write assembly [54] through a cylindrical nozzle. Then, the yielded multilayer scaffold was infiltrated with epoxy resin. When the resin was consolidated, structural matrix was obtained. With the help of heating and light vacuum, the fugitive ink was removed and 3D microvascular networks were created. By inserting a syringe tip into an open channel at one end of the microvascular networks, fluidic polymerizable healing agent was injected into the networks.

The healing chemistry of this method used ringopening metathesis polymerization of dicyclopentadiene (DCPD) monomer by Grubbs' catalyst, benzylidenebis(tricyclohexylphosphine) dichlororuthenium, which was used successfully in microencapsulated composites [55]. In the crack plane, the healing agent interacted with the catalyst particles in the composites to initiate polymerization, rebonding the crack faces autonomously. After a sufficient time period, the cracks were healed and the structural integrity of the coating was restored. As cracks reopened under subsequent loading, the healing cycle was repeated.

By means of four-point bending configuration monitored with an acoustic-emission sensor, the above approach proved to be feasible. The authors imagined extending this approach further to integrate pumps, valves and internal reservoirs, as well as to introduce new functionalities, including selfdiagnosis or self-cooling, through the circulation of molecular signals, coolants or other species [53].

To provide theoretical understanding how to vascularize a self-healing composite material so that healing fluid reaches all the crack sites that may occur randomly through the material, Bejana et al. studied the network configuration that is capable of delivering fluid to all the cracks the fastest [56]. When crack site dimension and total volume of the channels were fixed, it was argued that the network must be configured as a grid and not as a tree. In addition, it is beneficial to use a grid structure that has two channel sizes, $D_{1}$ and $D_{2}$, provided that the ratio $D_{1} / D_{2}$ is optimized. The crack-filling time can 
be reduced to $50 \%$ of the time required when the grid contains channels of only one size.

\subsection{Self-healing in terms of healant loaded microcapsules}

The principle of this approach resembles the aforesaid pipelines but the containers for storing healing agent are replaced by fragile microcapsules. Because the technique of microencapsulation has been rapidly developed since its emergency in 1950s [57-59] and mass production of microcapsules can be easily industrialized, self-healing composites might be thus used in practice accordingly. Jung et al. prepared a self-healing polyester composite with pre-embedded polyoxymethylene urea (PMU) microspheres [60]. The crack repair agent is mostly composed of styrene monomers and high molecular weight polystyrene. The latter helps to lower the rate of diffusion of styrene or diethenyl benzene into polyester matrix. The system of $23 \%$ polystyrene $\left(M_{n}=2.5 \cdot 10^{5}\right), 76.99 \%$ styrene and a trace amount of inhibitor proved to offer the optimum healing efficiency. Jung et al. also tried to utilize epoxide monomer loaded PMU microcapsules for rebinding the cracked faces in polyester matrix [60]. Solidification of the epoxy resin (i.e. the repair action) was triggered by the naturally occurring functional sites or embedded amine in the composites. In a latter work by White et al. [61], it was considered that the method was not feasible as the amine groups did not retain sufficient activity. Zako et al. proposed an intelligent material system using $40 \%$ volume fraction unmodified epoxy particles to repair microcracks and delamination damage in a glass/epoxy composite laminate [62]. By heating to $120^{\circ} \mathrm{C}$, the embedded epoxy particles $(\sim 50 \mu \mathrm{m})$ would melt, flow to the crack faces and repair the damage with the help of the excessive amine in the composite. In addition to the poor activity of the amine as mentioned above, manual intervention (i.e. heating) was necessary in this case.

We reported a two-component healant consisting of epoxy-loaded microcapsules as the polymerizable part and 2-methylimidazole/ $\mathrm{CuBr}_{2}$ complex $\left(\mathrm{CuBr}_{2}(2-\mathrm{MeIm})_{4}\right)$ as the latent hardener, which was pre-dispersed in composites' matrix to fabricate self-healing composites [63]. As soon as cracks destroyed the capsules, the epoxy oligomer would be released into the crack planes due to capillary effect and cured under initiation of the latent hardener at a temperature ranging from 130 to $180^{\circ} \mathrm{C}$. The features of this healing system lie in the following. (i) When the healing agent is applied to epoxy based composites, the miscibility between the crack adhesive and matrix is guaranteed because of identity of their species. (ii) The latent hardener possesses long-term stability and is hardly affected by the surrounding environment [64, 65]. Moreover, it can be well pre-dissolved in uncured composites' matrix, leading to homogenous distribution of the reagent on the molecular scale. Thus the epoxy released from the ruptured microcapsules might meet the latent hardener everywhere (Figure 3). The two-component healant is able to take effect in the woven glass fabric/epoxy composite laminates $[63,66]$.

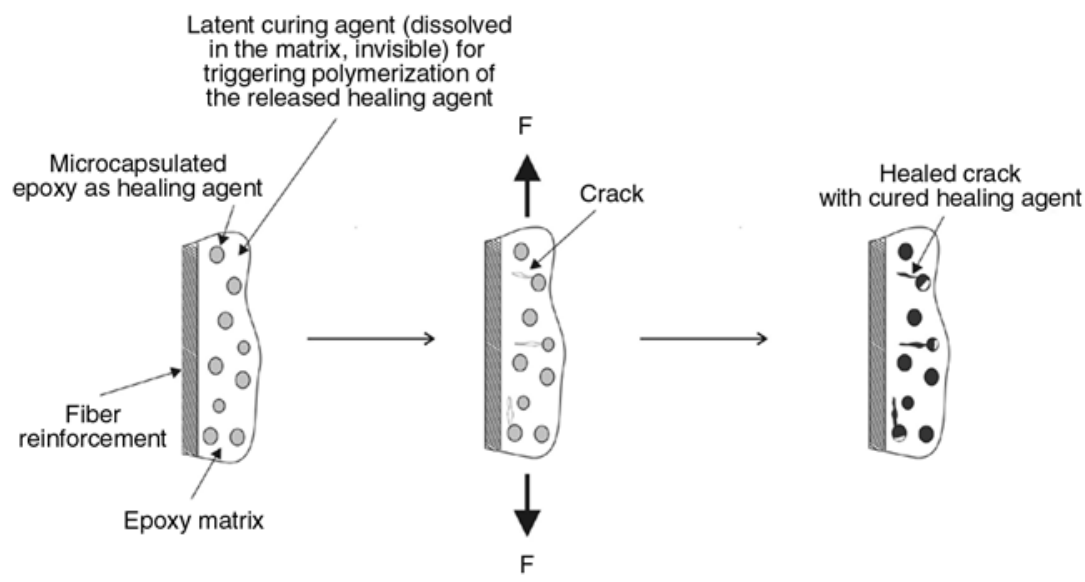

Figure 3. Schematic drawing of the principle of self-healing epoxy based laminates with epoxy loaded microcapsules and latent hardener [63] (Reprinted from Composites Science \& Technology, Vol 67, Yin T., Rong M. Z., Zhang M. Q., Yang G. C.: Self-healing epoxy composites - Preparation and effect of the healant consisting of microencapsulated epoxy and latent curing agent, 201-212, Copyright (2007), with permission from Elsevier) 


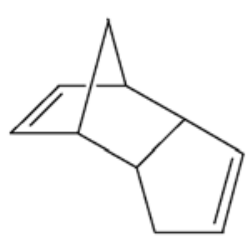

DCPD

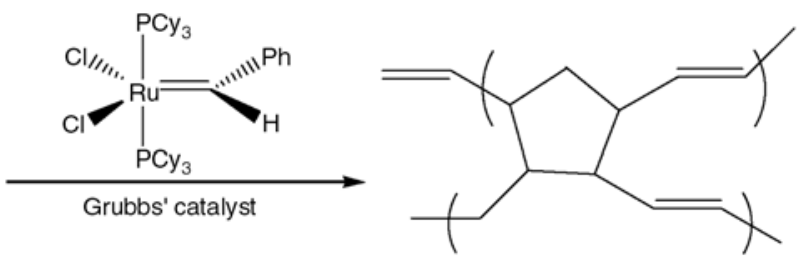

poly(DCPD)

Figure 4. Ring opening metathesis polymerization of DCPD

The group of White et al., the pioneer in developing self-healing polymeric materials, systematically investigated self-healing strategy based on ring opening metathesis polymerization (ROMP) of microencapsulated dicyclopentadiene (DCPD) and reported a series of important findings [55, 67-78]. Healing is triggered when damage in the form of a crack ruptures the microcapsules, causing DCPD to be released into the crack plane where it comes in contact and mixes with the pre-embedded Grubbs' catalyst (Figure 4). For increasing catalysis efficiency, the catalyst was capsulated by wax and recrystallized, respectively [70, 71]. Delamination damage in woven glass/epoxy composites was found to be repaired by the healing agent $[72,73]$. In addition, fatigue crack growth in epoxy can also be retarded by the released fluid [74-76].

Effect of DCPD loaded microcapsule size on the performance of self-healing polymers was studied [78]. Rule et al. indicated that the amount of liquid that microcapsules deliver to a crack face changed linearly with microcapsule diameter for a given weight fraction of capsules. Self-healing performance reached maximum levels only when sufficient healing agent was available to entirely fill the crack. Based on these relationships, the size and weight fraction of microcapsules can be rationally chosen to give optimal healing of a predetermined crack size. By using this strategy, self-healing was demonstrated with smaller microcapsules and with lower weight fractions of microcapsules. Blaiszik et al. further produced smaller capsules (down to $220 \mathrm{~nm}$ ) using sonication techniques and an ultrahydrophobe to stabilize the DCPD droplets [79]. It is believed that the nanocapsules will make selfhealing materials responsive to damage initiated at a scale that is not currently possible and compatible with composites where the reinforcement spacing requires smaller capsules for applications such as self-healing thin films, coatings, and adhesives.

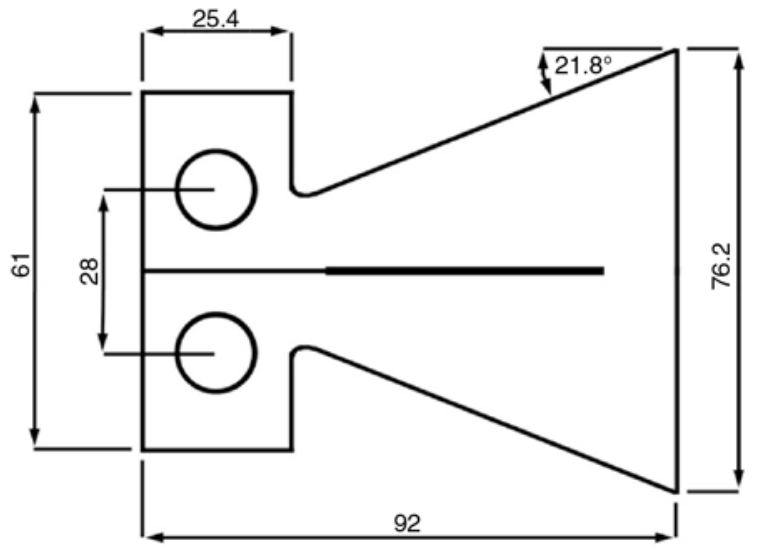

Figure 5. Schematic drawing of a TDCB specimen [78] (Reprinted from Polymer, Vol 48, Rule J. D., Sottos N. R., White S. R., Effect of microcapsule size on the performance of self-healing polymers, 3520-3529, Copyright (2007), with permission from Elsevier)

Comparison of fracture toughness of original specimen with that of healed one used to be a measure of healing effect. Conventional single-edge notched bending (SENB) and compact tension (CT) tests might be problematic in this case, as the prenotches would be partly closed after healing process and an accurate measurement cannot be guaranteed. To overcome the difficulty, White et al. proposed a testing protocol with a tapered double cantilever beam (TDCB) configuration (Figure 5) [67, 69]. The specific geometry ensures that the measured fracture toughness is nearly independent of pre-crack length, so that healing efficiency can be precisely determined.

The researches so far suggest that one of the key issues of self-healing composites by means of microencapsulation lies in rigidity of the shell substance and matrix. Like the case of hollow tubes discussed hereinbefore, crack trigger in microsphere embedded composites depends on matching of deformation characteristics of the related materials. Route of crack propagation is a function of the stiffness ratio of microcapsules and matrix [55]. If 
the inclusion has higher modulus than the matrix, the approaching crack tends to pass by the microcapsules; conversely, the crack could penetrate the microcapsules when the matrix is stiffer. On the other hand, simulation experiments manifest that the difference in fracture toughness of the microcapsules and matrix should be less than $0.11 \mathrm{MPa} \cdot \mathrm{m}^{1 / 2}$ [80]. Otherwise, cracks would not pass through the microcapsules.

The other critical factors include (i) good adhesion between microencapsulated healing agent and the matrix, (ii) size and concentration of microencapsulated healing agent, (iii) rate and degree of polymerization of the released healing agent, and (iv) shell thickness and core content of the microencapsulated healing agent.

In contrast to the above methods, Cho et al. dispersed phase-separated droplets of hydroxyl endfunctionalized polydimethylsiloxane (HOPDMS) and polydiethoxysiloxane (PDES) into a vinyl ester matrix, in which the catalyst, di- $n$-butyltin dilaurate (DBTL), contained within polyurethane microcapsules, were pre-embedded [81]. Polycondensation of HOPDMS with PDES occurred when they met the tin-catalyst from the broken capsules induced by mechanical damage. This system possesses some advantages, including (i) the healing chemistry remains stable in humid or wet environments, (ii) the chemistry is stable to an elevated temperature $\left(>100^{\circ} \mathrm{C}\right)$, enabling healing in higher-temperature thermoset systems, (iii) the components are widely available and comparatively low in cost, and (iv) the concept of phase separation of the healing agent simplifies processing, as the healing agent can now be simply mixed into the polymer matrix.

As for crack repair in elastomer, Keller et al. incorporated poly(urea-formaldehyde) (UF) walled microcapsules, which contained the constituent resin and initiator, respectively, into poly(dimethyl siloxane) (PDMS) [82]. The resin microcapsules were loaded with high-molecular weight vinyl functionalized PDMS and platinum catalyst complexes, while the initiator microcapsules contained a PDMS copolymer with active sites that would link to the vinyl functionalized resin via the action of the platinum catalyst. Damage triggering and healing events took place in an analogous way to the original self-healing epoxy described above. A propagating tear in the PDMS material intersected both resin and initiator microcapsules and ruptured them. The liberated healing fluids then wicked onto the tear plane through capillary action and mix. A crosslinking reaction, the same reaction that polymerized the matrix material, occurred and formed an adhesive polymer layer that rebonded the tear faces. This self-healing material system possesses the unique feature that the healed polymer in the crack plane is the same as the host matrix.

In addition to the polymerizable healing agent, Caruso et al. used solvents to heal cracks in thermoset materials [83]. Chlorobenzene was encapsulated by urea-formaldehyde and embedded in epoxy matrix. It is believed that the solvent would induce crosslinking of the incompletely cured resin and heal cracks. The technique might be an economical, simple, and potentially robust alternative to the recovery of virgin properties of a material after crack damage has occurred.

\section{Conclusions}

Achievements in the field of self-healing polymers and polymer composites are far from satisfactory, but the new opportunities that were found during research and development have demonstrated it is a challenging job to either invent new polymers with inherent crack repair capability or integrate existing materials with novel healing system. Interdisciplinary studies based on tight collaboration among scientists are prerequisites for overcoming the difficulties. Comparatively, extrinsic self-healing techniques might be easier for large-scale usage for the moment. The works and outcomes in this aspect have broadened the application possibility of polymeric materials. Also, the extended service life of components made from these intelligent materials would contribute to reduce waste disposal. It is undoubtedly important for building up a sustainable society.

Besides the approaches described in the above text (Table 1), ongoing attempts are continuously presenting new concepts. For example, Lee et al. considered solid-state devices that integrate ductile polymeric layers and brittle semiconductor or metal films [84]. Using computer simulations, they showed that adding nanoparticles to the polymers yielded materials in which the particles became localized at nanoscale cracks and effectively form 'patches' to repair the damaged regions. Trau et al. 
Table 1. Self-healing in polymers and polymer composites

\begin{tabular}{|c|c|c|c|c|c|c|}
\hline $\begin{array}{l}\text { Category of } \\
\text { materials to be } \\
\text { repaired }\end{array}$ & $\begin{array}{l}\text { Materials to be } \\
\text { repaired }\end{array}$ & Healing system & $\begin{array}{c}\text { Trigger } \\
\text { mechanism }\end{array}$ & $\begin{array}{c}\text { Healing } \\
\text { mechanism }\end{array}$ & $\begin{array}{l}\text { Assessment of } \\
\text { healing effect }\end{array}$ & Ref. \\
\hline Thermoplastic & $\begin{array}{l}\text { Poly(methyl } \\
\text { methacrylate), etc. }\end{array}$ & Bulk & $\begin{array}{l}\text { Heating or solvent } \\
\text { induced }\end{array}$ & $\begin{array}{l}\text { Chain interdiffu- } \\
\text { sion and entangle- } \\
\text { ments }\end{array}$ & $\begin{array}{l}\text { Compact tension } \\
\text { (CT) test or pho- } \\
\text { tography }\end{array}$ & {$[10,16,17]$} \\
\hline Thermoplastic & $\begin{array}{l}\text { Poly(ethylene-co- } \\
\text { methacrylic acid) }\end{array}$ & Bulk & $\begin{array}{l}\text { Thermomechani- } \\
\text { cally induced } \\
\text { melting }\end{array}$ & $\begin{array}{l}\text { Chain interdiffu- } \\
\text { sion and entangle- } \\
\text { ments }\end{array}$ & $\begin{array}{l}\text { Visual inspection } \\
\text { after sawing, cut- } \\
\text { ting and puncture }\end{array}$ & {$[18]$} \\
\hline Thermoplastic & Polycarbonate & $\begin{array}{l}\text { Bulk (weak } \\
\text { alkali/hydrolyzed } \\
\text { chains) }\end{array}$ & Steam & $\begin{array}{l}\text { Weak alkali cat- } \\
\text { alyzed polymer- } \\
\text { ization }\end{array}$ & $\begin{array}{l}\text { Molecular weight } \\
\text { and mechanical } \\
\text { strength }\end{array}$ & [25] \\
\hline Thermoplastic & $\begin{array}{l}\text { Poly(phenylene } \\
\text { ether) }\end{array}$ & $\begin{array}{l}\text { Bulk (copper } \\
\text { ion/oxygen/scis- } \\
\text { sion chains) }\end{array}$ & Heating & $\begin{array}{l}\text { Copper ion cat- } \\
\text { alyzed polymer- } \\
\text { ization }\end{array}$ & Molecular weight & [26] \\
\hline Thermoset & Epoxy & Bulk & Heating & $\begin{array}{l}\text { Post-curing of } \\
\text { residual functional } \\
\text { groups }\end{array}$ & Impact strength & {$[19,20]$} \\
\hline $\begin{array}{l}\text { Thermoplastic/ther } \\
\text { moset semi-inter- } \\
\text { penetrating net- } \\
\text { work }\end{array}$ & $\begin{array}{l}\text { Poly(bisphenol-A- } \\
\text { co-epichlorohy- } \\
\text { drin)/epoxy }\end{array}$ & Bulk & Heating & $\begin{array}{l}\text { Chain interdiffu- } \\
\text { sion and entangle- } \\
\text { ments }\end{array}$ & $\begin{array}{l}\text { CT and impact } \\
\text { tests; photography }\end{array}$ & {$[22,23]$} \\
\hline $\begin{array}{l}\text { Thermally } \\
\text { reversible } \\
\text { crosslinking net- } \\
\text { work }\end{array}$ & $\begin{array}{l}\text { Crosslinked multi- } \\
\text { furan/multi- } \\
\text { maleimide }\end{array}$ & Bulk & Heating & $\begin{array}{l}\text { Diels-Alder reac- } \\
\text { tion }\end{array}$ & $\begin{array}{l}\text { CT and double } \\
\text { cleavage drilled } \\
\text { compression }\end{array}$ & {$[27,28,31]$} \\
\hline Thermoset & $\begin{array}{l}\text { Epoxy, fiber/unsat- } \\
\text { urated polyester, } \\
\text { and fiber/epoxy }\end{array}$ & $\begin{array}{l}\text { Cyanoacrylate, } \\
\text { epoxy, unsaturated } \\
\text { polyester, etc. }\end{array}$ & $\begin{array}{l}\text { Crack induced } \\
\text { breakage of hol- } \\
\text { low tubes contain- } \\
\text { ing healant }\end{array}$ & Curing of healant & $\begin{array}{l}\text { Tensile, flexural } \\
\text { and impact tests; } \\
\text { photography; } \\
\text { ultrasonic C-scan }\end{array}$ & [32-48] \\
\hline Thermoset & Epoxy & $\begin{array}{l}\text { Dicyclopentadi- } \\
\text { ene/Grubbs' cata- } \\
\text { lyst }\end{array}$ & $\begin{array}{l}\text { Crack induced } \\
\text { damage of 3D } \\
\text { microvascular net- } \\
\text { works, releasing } \\
\text { healant }\end{array}$ & $\begin{array}{l}\text { Ring-opening } \\
\text { metathesis poly- } \\
\text { merization of } \\
\text { healan }\end{array}$ & $\begin{array}{l}\text { Four-point bend- } \\
\text { ing }\end{array}$ & [53] \\
\hline Thermoset & $\begin{array}{l}\text { Unsaturated poly- } \\
\text { ester }\end{array}$ & Styrene or epoxy & $\begin{array}{l}\text { Crack induced rup- } \\
\text { ture of microen- } \\
\text { capsulated healant }\end{array}$ & $\begin{array}{l}\text { Polymerization or } \\
\text { curing of healant }\end{array}$ & $\begin{array}{l}\text { Mechanical } \\
\text { strength and visual } \\
\text { inspection }\end{array}$ & {$[60]$} \\
\hline Thermoset & Glass fiber/epoxy & Epoxy granules & Heating & Curing of healant & $\begin{array}{l}\text { Three-point bend- } \\
\text { ing and tensile } \\
\text { fatigue }\end{array}$ & {$[62]$} \\
\hline Thermoset & $\begin{array}{l}\text { Epoxy and woven } \\
\text { glass fiber/epoxy }\end{array}$ & $\begin{array}{l}\text { Epoxy/latent hard- } \\
\text { ener }\end{array}$ & $\begin{array}{l}\text { Crack induced rup- } \\
\text { ture of microen- } \\
\text { capsulated epoxy }\end{array}$ & Curing of healant & $\begin{array}{l}\text { Single edge } \\
\text { notched bend } \\
\text { (SENB) and dou- } \\
\text { ble cantilever } \\
\text { beam (DCB) tests }\end{array}$ & [63] \\
\hline Thermoset & $\begin{array}{l}\text { Epoxy, fiber/unsat- } \\
\text { urated polyester, } \\
\text { and fiber/epoxy }\end{array}$ & $\begin{array}{l}\text { Dicyclopentadi- } \\
\text { ene/Grubbs' cata- } \\
\text { lyst }\end{array}$ & $\begin{array}{l}\text { Crack induced rup- } \\
\text { ture of microen- } \\
\text { capsulated healant }\end{array}$ & $\begin{array}{l}\text { Ring-opening } \\
\text { metathesis poly- } \\
\text { merization of } \\
\text { healant }\end{array}$ & $\begin{array}{l}\text { Tapered double } \\
\text { cantilever beam } \\
\text { (TDCB), DCB and } \\
\text { fatigue tests }\end{array}$ & {$[55,67-78]$} \\
\hline Thermoset & $\begin{array}{l}\text { Unsaturated poly- } \\
\text { ester }\end{array}$ & $\begin{array}{l}\text { Phase-separated } \\
\text { polysiloxane } \\
\text { droplets/tin cata- } \\
\text { lyst }\end{array}$ & $\begin{array}{l}\text { Crack induced rup- } \\
\text { ture of microen- } \\
\text { capsulated catalyst }\end{array}$ & $\begin{array}{l}\text { Polycondensation } \\
\text { of polysiloxanes }\end{array}$ & TDCB & [81] \\
\hline Elastomer & Silicone rubber & $\begin{array}{l}\text { Polysiloxane/plat- } \\
\text { inum catalyst/ini- } \\
\text { tiator }\end{array}$ & $\begin{array}{l}\text { Crack induced rup- } \\
\text { ture of microen- } \\
\text { capsulated healant } \\
\text { and initiator }\end{array}$ & $\begin{array}{l}\text { Polycondensation } \\
\text { of polysiloxanes }\end{array}$ & Tear strength & [82] \\
\hline Thermoset & Epoxy & $\begin{array}{l}\text { Solvent } \\
\text { (chlorobenzene) }\end{array}$ & $\begin{array}{l}\text { Crack induced rup- } \\
\text { ture of microen- } \\
\text { capsulated solvent }\end{array}$ & $\begin{array}{l}\text { Solvent induced } \\
\text { crosslinking of } \\
\text { incompletely } \\
\text { cured resin }\end{array}$ & TDCB & [83] \\
\hline
\end{tabular}


proposed healing under electric field in terms of electrohydrodynamic aggregation of colloidal dielectric particles [85]. By creating a semi-interpenetrating network composed of a crosslinked thermoset and a thermoplastic, Karger-Kocsis considered that both shape memory and self healing functions can be combined [86]. In such a intelligent material, the thermoplastic polymer (amorphous or semicrystalline) offers 'switching' and 'healing' effects, whereas the crossliniked thermoset acts as the fixing phase.

From a long-term point of view, synthesis of brandnew polymers accompanied by intrinsic self-healing function through molecular design would be a reasonable solution. Recent exploration has shown the prospects of this trend, but the automatic trigger mechanism remains open. Working out the solutions would certainly push polymer sciences and engineering forward.

\section{Acknowledgements}

The authors are grateful to the support of the Natural Science Foundation of China (Grants: 50573093, U0634001).

\section{References}

[1] Riefsnider K. L., Schulte K., Duke J. C.: Long term failure behavior of composite materials. ASTM Special Technical Publications, 813, 136-159 (1983).

[2] Trask R. S., Williams H. R., Bond I. P.: Self-healing polymer composites: Mimicking nature to enhance performance. Bioinspiration and Biomimetics, 2, 1-9 (2007).

[3] Hastings G. W., Mahmud E. A.: Intelligent orthopaedic materials. Journal of Intelligent Material Systems and Structure, 4, 452-457 (1993).

[4] Martin P.: Wound healing-aiming for perfect skin regeneration. Science, 276, 75-81 (1997).

[5] Caplan A. I.: Bone development, cell and molecular biology of vertebrate hard tissues. Ciba Foundation Symposium, 136, 3-21 (1988).

[6] Albert S. F., Wong E.: Electrical stimulation of bone repair. Clinics in Podiatric Medicine and Surgery, 8, 923-935 (1981).

[7] Wool R. P., O'Connor K. M.: A theory of crack healing in polymers. Journal of Applied Physics, 52, 5953-5963 (1981).

[8] Wool R. P., Yuan B-L., McGarel O. J.: Welding of polymer interfaces. Polymer Engineering and Science, 29, 1340-1367 (1989).

[9] Kim Y. H., Wool R. P.: A theory of healing at a polymer-polymer interface. Macromolecules, 16, 11151120 (1983).
[10] Jud K., Kaush H. H.: Load transfer through chain molecules after interpenetration at interfaces. Polymer Bulletin, 1, 1697-1707 (1979).

[11] Kaush H. H., Jud K.: Molecular aspects of crack formation and healing in glassy polymers. Plastics and Rubber Processing and Applications, 2, 265-268 (1982)

[12] Wool R. P.: Relation for healing, fracture, self-diffusion and fatigue of random coil polymers. American Chemical Society, Polymer Preprints, 23, 62-63 (1982).

[13] Jud K., Kausch H. H., Williams J. G.: Fracture mechanics studies of crack healing and welding of polymers. Journal of Materials Science, 16, 204-210 (1981).

[14] McGarel O. J., Wool R. P.: Craze growth and healing in polystyrene. Journal of Polymer Science, Part B: Polymer Physics, 25, 2541-2560 (1987).

[15] Wool R. P., Rockhill A. T.: Molecular aspects of fracture and crack healing in glassy polymers. American Chemical Society, Polymer Preprints, 21, 223-224 (1980).

[16] Lin C. B., Lee S., Liu K. S.: Methanol-induced crack healing in poly(methyl methacrylate. Polymer Engineering and Science, 30, 1399-1406 (1990).

[17] Wang P-P., Lee S., Harmon J.: Ethanol-induced crack healing in poly(methyl methacrylate). Journal of Polymer Science, Part B: Polymer Physics, 32, 1217-1227 (1994).

[18] Kalista S. J., Ward T. C.: Thermal characteristics of the self-healing response in poly(ethylene-comethacrylic acid) copolymers. Journal of the Royal Society: Interface, 4, 405-411 (2007).

[19] Outwater J. O., Gerry D. J.: On the fracture energy, rehearing velocity and refracture energy of cast epoxy resin. Journal of Adhesion, 1, 290-298 (1969).

[20] Wool R. P.: Polymer interfaces: Structure and strength. Hanser, Munich, (1994).

[21] Jayarama R., Wool R. P.: Interfaces in repair, recycling, joining and manufacture of polymers and polymer composites. Journal of Applied Polymer Science, 71, 775-785 (1999).

[22] Hayes S. A., Jones F. R., Marshiya K., Zhang W.: A self-healing thermosetting composite material. Composites, Part A: Applied Science and Manufacturing, 38, 1116-1120 (2007).

[23] Hayes S. A., Zhang W., Branthwaite M., Jones F. R.: Self-healing of damage in fibre-reinforced polymermatrix composites. Journal of the Royal Society: Interface, 4, 381-387 (2007).

[24] Hayes S. A., Jones F. R.: Self healing composite materials. UK Patent, GB0500242.3. (2004).

[25] Takeda K., Unno H., Zhang M.: Polymer reaction in polycarbonate with $\mathrm{Na}_{2} \mathrm{CO}_{3}$. Journal of Applied Polymer Science, 93, 920-926 (2004).

[26] Takeda K., Tanahashi M., Unno H.: Self-repairing mechanism of plastics. Science and Technology of Advanced Materials, 4, 435-444 (2003). 
[27] Chen X., Dam M. A., Ono K., Mal A., Shen H., Nutt S. R., Sheran K., Wudl F.: A thermally re-mendable cross-linked polymeric material. Science, 295, 16981702 (2002).

[28] Chen X., Wudl F., Mal A. K., Shen H., Nutt S. R.: New thermally remendable highly cross-linked polymeric materials. Macromolecules, 36, 1802-1807 (2003).

[29] Liu Y-L., Hsieh C-Y.: Crosslinked epoxy materials exhibiting thermal remendablility and removability from multifunctional maleimide and furan compounds. Journal of Polymer Science, Part A: Polymer Chemistry, 44, 905-913 (2006).

[30] Liu Y-L., Chen Y-W.: Thermally reverible crosslinked polyamides with high toughness and selfrepairing ability from maleimide- and furan-functionalized aromatic polyamides. Macromolecular Chemistry and Physics, 208, 224-232 (2007).

[31] Plaisted T. A., Nemat-Nasser S.: Quantitative evaluation of fracture, healing and re-healing of a reversibly cross-linked polymer. Acta Materialia, 55, 5684-5696 (2007).

[32] Dry C.: Passive tunable fibers and matrices. International Journal of Modern Physics, B, 6, 2763-2771 (1992).

[33] Dry C.: Matrix cracking repair and filling using active and passive modes for smart timed release of chemicals from fibers into cement matrices. Smart Materials and Structures, 3, 118-123 (1994).

[34] Dry C., McMillan W.: Three-part methylmethacrylate adhesive system as an internal delivery system for smart responsive concrete. Smart Materials and Structures, 5, 297-300 (1996).

[35] Dry C.: Procedures developed for self-repair of polymer matrix composite materials. Composite Structures, 35, 263-269 (1996).

[36] Motuku M., Vaidya U. K., Janowski C. M.: Parametric studies on self-repairing approaches for resin infused composites subjected to low velocity impact. Smart Materials and Structures, 8, 623-638 (1999).

[37] Zhao X. P., Zhou B. L., Luo C. R., Wang J. H., Liu J. W.: A model of intelligent material with self-repair function (in Chinese). Chinese Journal of Materials Research, 10, 101-104 (1996).

[38] Bleay S. M., Loader C. B., Hawyes V. J., Humberstone L., Curtis P. T.: A smart repair system for polymer matrix composites. Composites, Part A: Applied Science and Manufacturing, 32, 1767-1776 (2001).

[39] Dry C., Sottos N. R.: Passive smart self-repair in polymer matrix composite materials. Proceedings of SPIE - The International Society for Optical Engineering, 1916, 438-444 (1993).

[40] Dry C., McMillan W.: Crack and damage assessment in concrete and polymer matrices using liquids released internally from hollow optical fibers. Proceedings of SPIE - The International Society for Optical Engineering, 2718, 448-451 (1996).

[41] Dry C., Haven P.: Smart-fiber-reinforced matrix compositions. US patent 5803963, USA (1998).
[42] Dry C., Line S., Winona M.: Self-repairing reinforced matrix materials. US patent 7022179 B1, USA (2006).

[43] Motuku M., Janowski G. M., Vaidya U. K., Mahfuz H., Jeelani S.: Low velocity impact characterization of unreinforced vinyl ester 411-350 and 411-C50 resin systems. Polymer and Polymer Composites, 7, 383407 (1999).

[44] Pang J. W. C., Bond I. P.: A hollow fibre reinforced polymer composite encompassing self-healing and enhanced damage visibility. Composites Science and Technology, 65, 1791-1799 (2005).

[45] Pang J. W. C., Bond I. P.: 'Bleeding composites'damage detection and self-repair using a biomimetic approach. Composites, Part A: Applied Science and Manufacturing, 36, 183-188 (2005).

[46] Trask R. S., Bond I. P.: Biomimetic self-healing of advanced composite structures using hollow glass fibres. Smart Materials and Structures, 15, 704-710 (2006).

[47] Trask R. S., Williams G. J., Bond I. P.: Bioinspired self-healing of advanced composite structures using hollow glass fibres. Journal of the Royal Society: Interface, 4, 363-371 (2007).

[48] Williams G., Trask R. S., Bond I. P.: A self-healing carbon fibre reinforced polymer for aerospace applications. Composites, Part A: Applied Science and Manufacturing, 38, 1525-1532 (2007).

[49] Yang H., Liang D., Tao B., Qiu H.: Application and influence of hollow optical fiber embedded in fiber glass/epoxy composite materials (in Chinese). Transactions of Nanjing University of Aeronautics and Astronautics, 17, 130-134 (2000).

[50] Yang H., Liang D. K., Tao B. Q., Huang M. S., Qiu $\mathrm{H}$.: Research on the performance and application of hollow-center optical fiber in smart material (in Chinese). Materials Science and Engineering, 18, 27-30 (2000).

[51] Yang H., Liang D. K., Tao B. Q., Qiu H., Cao Z. X.: Research on self-diagnose and self-repair using hollow-center optical fiber in smart structure (in Chinese). Journal of Functional Materials, 32, 419-424 (2001).

[52] Hiemstra D. L., Sottos N. R.: Thermally induced interfacial microcracking in polymer matrix composites. Journal of Composite Materials, 27, 1030-1051 (1993).

[53] Toohey K. S., Sottos N. R., Lewis J. A., Moore J. S., White S. R.: Self-healing materials with microvascular networks. Nature Materials, 6, 581-585 (2007).

[54] Therriault D., Shepherd R. F., White S. R., Lewis J. A.: Fugitive inks for direct-write assembly of threedimensional microvascular networks. Advanced Materials, 17, 394-399 (2005).

[55] White S. R., Sottos N. R., Geubelle P. H., Moore J. S., Kessler M. R., Sriram S. R., Brown E. N., Viswanathan S.: Autonomic healing of polymer composites. Nature, 409, 794-797 (2001). 
[56] Bejan A., Lorente S., Wang K-M.: Networks of channels for self-healing composite materials. Journal of Applied Physics, 100, 033528/1-033528/6 (2006).

[57] Gardner G. L.: Manufacturing encapsulated products. Chemical Engineering Progress, 62, 87-91 (1966).

[58] Fanger G. O.: What good are microcapsules? Chemtech, 4, 397-405 (1974).

[59] Song J., Chen L., Li X. J.: Microencapsulation and its application (in Chinese). Chemical Engineering Press, Beijing, (2001).

[60] Jung D., Hegeman A., Sottos N. R., Geubelle P. H., Whites S. R.: Self-healing composites using embedded microspheres. in 'Proceedings of the ASME International Mechanical Engineering Congress and Exposition, Dallas, USA', Vol MD-80, 265-275 (1997).

[61] White S. R., Sottos N. R., Geubelle P. H., Moore J. S., Siriram S. R., Kessler M. R., Brown E. N.: Multifunctional autonomically healing composite material. US Patent 6858 659, USA, (2005).

[62] Zako M., Takano N.: Intelligent material systems using epoxy particles to repair microcracks and delamination damage in GFRP. Journal of Intelligent Material Systems and Structure, 10, 836-841 (1999).

[63] Yin T., Rong M. Z., Zhang M. Q., Yang G. C.: Selfhealing epoxy composites- Preparation and effect of the healant consisting of microencapsulated epoxy and latent curing agent. Composites Science and Technology, 67, 201-212 (2007).

[64] Dowbenko R., Anderson C. C., Chang W. H.: Imidazole complexes as hardeners for epoxy adhesives. Industrial and Engineering Chemistry Product Research and Development, 10, 344-351 (1971).

[65] Ibonai M., Kuramochi T.: Curing of epoxy resin by use of imidazole/metal complexes (in Japanese). Reinforced Plastics, 26, 69-73 (1975).

[66] Yin T., Zhou L., Rong M. Z., Zhang M. Q.: Self-healing woven glass fabric/epoxy composites with the healant consisting of micro-encapsulated epoxy and latent curing agent. Smart Materials and Structures, 17, 015019/1-015019/8 (2008).

[67] Brown E. N, Sottos N. R., White S. R.: Fracture testing of a self-healing polymer composite. Experimental Mechanics, 42, 372-379 (2002).

[68] Brown E. N., White S. R., Sottos N. R.: Microcapsule induced toughening in a self-healing polymer composite. Journal of Materials Science, 39, 1703-1710 (2004).

[69] Rule J. D., Sottos N. R., White S. R., Moore J. S.: The chemistry of self-healing polymers. Education in Chemistry, 42, 130-132 (2005).

[70] Rule J., Brown E. N., Sottos N. R., White S. R., Moore J. S.: Wax-protected catalyst microspheres for efficient self-healing materials. Advanced Materials, 72, 205-208 (2005).

[71] Jones A. S., Rule J. D., Moore J. S., White S. R., Sottos N. R.: Catalyst morphology and dissolution kinetics of self-healing polymers. Chemistry of Materials, 18, 1312-1317 (2006).
[72] Kessler M. R., White S. R.: Self-activated healing of delamination damage in woven composites. Composites, Part A: Applied Science and Manufacturing, 32, 683-699 (2001).

[73] Kessler M. K., Sottos N. R., White S. R.: Self-healing structural composite material. Composites, Part A: Applied Science and Manufacturing, 34, 743-753 (2003).

[74] Brown E. N., White S. R., Sottos N. R.: Retardation and repair of fatigue cracks in a microcapsule toughened epoxy composite- Part I: Manual infiltration. Composites Science and Technology, 65, 2466-2473 (2005).

[75] Brown E. N., White S. R., Sottos N. R.: Retardation and repair of fatigue cracks in a microcapsule toughened epoxy composite- Part II: In situ self-healing. Composites Science and Technology, 65, 2474-2480 (2005).

[76] Jones A. S., Rule J. D., Moore J. S., Sottos N. R., White S. R.: Life extension of self-healing polymers with rapidly growing fatigue cracks. Journal of the Royal Society Interface, 4, 395-403 (2007).

[77] Wilson G. O., Moore J. S., White S. R., Sottos N. R., Andersson H. M.: Autonomic healing of epoxy vinyl esters via ring opening metathesis polymerization. Advanced Functional Materials, 18, 44-52 (2008).

[78] Rule J. D., Sottos N. R., White S. R.: Effect of microcapsule size on the performance of self-healing polymers. Polymer, 48, 3520-3529 (2007).

[79] Blaiszik B. J., Sottos N. R., White S. R.: Nanocapsules for self-healing materials. Composites Science and Technology, 68, 978-986 (2008).

[80] Yang Y., Zhang H., Zhang J., Wang S-H., Duan C-J., He Y-J.: The experiment study of fracture mechanics on self-healing composite material containing microcapsules (in Chinese). Materials Review, 21, 143-147 (2007).

[81] Cho S. H., Andersson H. M., White S. R., Sottos N. R., Braun P. V.: Polydimethylsiloxane-based selfhealing materials. Advanced Materials, 18, 997-1000 (2006).

[82] Keller M. K., White S. R., Sottos N. R.: A self-healing poly(dimethyl siloxane) elastomer. Advanced Functional Materials, 17, 2399-2404 (2007).

[83] Caruso M. M., Delafuente D. A., Ho V., Moore J. S., Sottos N. R., White S. R.: Solvent-promoted self-healing materials. Macromolecules, 40, 8830-8832 (2007).

[84] Lee J. Y., Buxton G. A., Balazs A. C.: Using nanoparticles to create self-healing composites. Journal of Chemical Physics, 121, 5531-5540 (2004).

[85] Trau M., Sankaran S., Saville D. A., Aksay I. A.: Electric-field-induced pattern formation in colloidal dispersions. Nature, 374, 437-439 (1995).

[86] Ratna D., Karger-Kocsis J.: Recent advances in shape memory polymers and composites: A review. Journal of Materials Science, 43, 254-269 (2008). 